\title{
Correction to: Using CPAP in COVID-19 patients outside of the intensive care setting: a comparison of survival and outcomes between dialysis and non- dialysis dependent patients
}

Lauren Floyd $^{1 *}$, Madelena Stauss ${ }^{1}$, Joshua Storrar ${ }^{1}$, Parthvi Vanalia ${ }^{1}$, Anna France ${ }^{2}$ and Ajay Dhaygude ${ }^{1}$

Correction to: BMC Nephrol 22, 144 (2021)

https://doi.org/10.1186/s12882-021-02341-x

Following publication of the original article [1], the authors informed us that accidently omitted to add the acknowledgements to NIHR Lancashire Clinical Research Facility. The Acknowledgements has been updated as follows:

\section{Acknowledgements \\ The authors would like to acknowledge the Renal Department at Royal Preston Hospital in addition to the Respiratory Department for their clinical support during the study period and sharing of data. \\ The research was supported by the NIHR Lancashire Clinical Research Facility. \\ The original article has been corrected.}

\section{Author details}

'Department of Nephrology, Royal Preston Hospital, Lancashire Teaching Hospitals NHS Foundation Trust, Preston, UK. ${ }^{2}$ University of Central

Lancashire, Lancashire, UK.

Published online: 10 May 2021

\section{Reference}

1. Floyd, et al. Using CPAP in COVID-19 patients outside of the intensive care setting: a comparison of survival and outcomes between dialysis and nondialysis dependent patients. BMC Nephrol. 2021;22:144. https://doi.org/10.11 86/s12882-021-02341-X.

The original article can be found online at https://doi.org/10.1186/s12882021-02341-x

* Correspondence: lauren.floyd@doctors.org.uk

'Department of Nephrology, Royal Preston Hospital, Lancashire Teaching Hospitals NHS Foundation Trust, Preston, UK

Full list of author information is available at the end of the article

(c) The Author(s). 2021 Open Access This article is licensed under a Creative Commons Attribution 4.0 International License, which permits use, sharing, adaptation, distribution and reproduction in any medium or format, as long as you give appropriate credit to the original author(s) and the source, provide a link to the Creative Commons licence, and indicate if changes were made. The images or other third party material in this article are included in the article's Creative Commons licence, unless indicated otherwise in a credit line to the material. If material is not included in the article's Creative Commons licence and your intended use is not permitted by statutory regulation or exceeds the permitted use, you will need to obtain permission directly from the copyright holder. To view a copy of this licence, visit http://creativecommons.org/licenses/by/4.0/ The Creative Commons Public Domain Dedication waiver (http://creativecommons.org/publicdomain/zero/1.0/) applies to the data made available in this article, unless otherwise stated in a credit line to the data. 